\title{
Problem of new marine silk road construction in china
}

\author{
Jiaying Wang \\ School of Finance, Changchun University of Finance and Economics, Changchun 130000, China
}

\begin{abstract}
President Xi Jinping advocated to build "silk road economic belt" during a trip to central Asian four countries in September 2013.In the same year, Xi Jinping visited Southeast Asia and pointed out that Southeast Asia is important hub of marine silk road since ancient times during a speech in congress of Indonesia, and China is willing to strengthen cooperation with members of ASEAN, to make most use of China-ASEAN marine cooperation fund built by China, to develop marine partnership, and to join in the joint construction of marine silk road in the $21 \mathrm{st}$ century. The two initiatives combine the history of friendly trade of ancient China and Asia, Africa, and European and reality economic exchanges, and give the new connotation of the time. This paper focuses on analyzing strategic significance and construction plan of new marine Silk Road in china.
\end{abstract}

\section{Historical Review of Marine Silk Road}

Before discussing China returning marine time Silk Road, It is necessary to review the development course of marine Silk Road. Marine Silk Road is a sea lane of Ancient China trading and cultural communication with foreign, whose development course can be roughly divided into several historical stages.

First, it formed in the qin and han dynasties. The marine Silk Road included the East China Sea routes and the South China Sea routes. The east China sea routes was mainly from the Korean peninsula to Japan and from the east coast to Japan, Taiwan and Taiwan islands; It was unknown that where the south China sea routes began in, but according to historical records, China silks had been introduced into India and western countries in the $4^{\text {th }}$ century at the latest. The Western-style silver ware that was unearthed from Guangdong King Zhao Tuo tomb in the end of the qin dynasty and the early of the han dynasty was suspected to be produced by Persia. The book han geography clearly documented the Emperor Wu pacifying south Guangdong, then sending envoy to Nan yang (an old name for southeast Asia) and India. Envoys finally returned after arriving Sri Lanka. In that time the ship was carrying a variety of silks. The Xuwen in Guangdong and Hepu in Guangxi was an important port of departure of the South China Sea routes.

Second, it developed in the tang dynasty. In the middle of tang dynasty, Silk Road gradually receded due to the war, which promoted the development of marine Silk Road. The invention of the compass needle allowed ships voyaging to the West Asian countries. As a result of the Jiangnan Silk, tea and a large number of china's exports, Quanzhou had become the world's largest trading port. Many Arabian relics in Quanzhou suggest that the trade between China and Western countries transited by merchant of Arab, so that Western countries launched the crusades, attempting to control this East-West trade route, but failed, which arouse the power of Western world to find another new marine route to the east.

Third, it thrived in the Yuan and Ming Dynasties period. The Yuan dynasty China government set up the trade department to manage overseas trade in the southeast coast including Ningbo, Quanzhou, Guangzhou, Wenzhou and Hangzhou. In order to display national power to foreign, Yongle Emperor of the Ming Dynasty sent Zheng He and his fleet to Atlantic, Zheng He had gone to the Atlantic seven times, which lasted for 28 years (AD 1405 - 1433), the most far destination is Kenya in Africa, which is the feat of world's maritime history. Large fleet brought silk, leaf, porcelain, gold and silver utensils, hardware, books and other products to those countries. The import goods mainly include: glass, jewelry, ivory, agate, spices, pepper, sandalwood and other items. But the voyages of Zheng $\mathrm{He}$ in Ming dynasty failed to sequentially to expand trade results; soon it was replaced by a marine prohibition policy.

Fourth, it began to change in the middle of Ming and Qing Dynasty. After Zheng He, the Ming government wills soon burned technical materials used in the construction of larger ships, and banned to manufacture large ships that can navigate. When Ming Dynasty government adopted a marine prohibition policy, boycott policy, the western world was entering the age of geography big discovery. The government of Chinese Qing dynasty also followed the prohibition policy of the Ming Dynasty, and allowed only one place in Guangzhou to trade with foreign. At this time, the western colonists almost monopolized the Silk Road on the sea. Based on the reality need of route of the ancient marine Silk Road

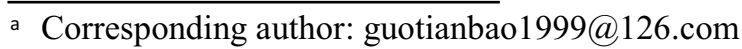


and the new period, the twenty-first Century Marine Silk Road should plan three strategic direction, including East, West, and north line. The west is an important channel of China going to South China Sea to contact in Asia Europe and Africa, and is a maritime lifeline of China's peaceful development, energy security and economic security; the east line go through the East China Sea to connect the South Pacific island countries to Latin America and North America, and is a important channel to break the sea blockade and to protect national security; North line is an important channel for the use of the Arctic Ocean shipping lane and the strengthen of the cooperation in Northeast Asia, which has strategic significance to the exploitation of polar resources in China.

\section{Background and significance of proposing new marine silk road}

The Belt and Road Initiative mainly make contribution to opening up and developing the Mideast areas of China, which was focus on westward opening and developing the developed country of the west. Developing the developed country of the west and the Great West Development Strategy is a major transition of China's opening up and regional development strategy. The implementation of China foreign strategic adjustment is mainly based on the following factors: on the one hand, opening up the development of Chinese eastern coastal caused the gap between eastern and western regional development continually to expand, while the Midwest is areas of China's minority, resulting in increased ethnic conflict and regional instability. On the other hand, the development of China's economy to the neighboring countries has a dual impact, neighboring countries enjoy the opportunity of China's economic development, at the same time, have a greater psychological protection to China. "Belt and Road" initiative is an important starting point for Chinese turn to the west, is a major adjustment of Chinese foreign strategy, but also gives a new meaning to the Silk Road.

First, new maritime Silk Road is focusing on delivering the peaceful information. The maritime silk road was formed in the Qin and Han Dynasty, 2000 years ago, and form a climax when Zheng he was travelling to the west ocean in Ming Dynasty, and left many remains in Southeast Asia, West Asia and Africa. These historical relations show that the historical Silk Road is a peaceful trade channel. China didn't conquer these countries along by opening trade channels, which is a sharp contrast with the full of conquest and plunder trade channel after large geographical discovery and opening trade route in modern western countries. The message China wants to pass is that China goes to the sea; will not repeat the old Western powers to compete for hegemony on the sea, but with a peaceful way. China's development will not threaten the economic, political and security of the Southeast Asian countries and countries along the Silk Road.

Secondly, it can create a new pattern of mutual benefit and win-win in Asia and achieve the Century Asian dream. In history, Asian countries have created some splendid civilization. There are Chinese civilization, India civilization, and Persian civilization and Arabia civilization. The Silk Road is an important link in the exchange and integration of these civilizations. Today the influence of Chinese economic is radiating in Asia, Africa and Latin America. The construction of modern maritime silk road is linking China to ASEAN countries, South Asian countries, and the Gulf countries by offshore interconnection, port city cooperation mechanisms and marine economic cooperation, to promote the interests of all countries, to expand the scope of economic cooperation and assistance, to provide public governance and public products, so that the Silk Road countries could share the dividend of Chinese economic development. China will also establish a great image of a responsible big country.

Thirdly, the new maritime Silk Road is of great economic strategic significance. China takes an important strategic interest in Southeast Asia and the Indian Ocean, the economic benefit and safety of route. In China, $80 \%$ of oil, $50 \%$ of gas imports, and $42.6 \%$ import and export goods go through the Silk Road. Latin America is important export market of resource in our country. The United States put forward the new Silk Road project, and get through the Indian Ocean and Pacific indo-pacific strategy. It also call on India to join contain circle in China, and combined with the Pacific island chain strategy to construct China encirclement. Construction of maritime silk road of China will break the deadlock, it combine the ancient silk road spirit that is generally recognized by the Eurasia countries with the advantage of China's economy, and it based on economy, to expand and deepen China along with the country's economic interests, to close relations of cooperation with each other, and to achieve common development and common safety, so that it conduce to eliminate the China threat theory, forming geopolitical and geo-economic pattern that make for China.

The fourth, is conducive to the realization of China 's strategic goal of building a maritime power. Historical experience has repeatedly revealed that facing the sea will be prosperous, backing to the sea will be recessionary, and running the sea is a necessary condition for the rise of great powers. Maritime Silk Road is a sign of China's prosperity; And Zheng He's voyages and closed-door policy are the root of China's decline. The construction of maritime Silk Road will become China's major strategic of running sea.

\section{Economy and trade status quo and countermeasure of china and "maritime silk road" asean countries}

\subsection{Economy and trade status quo and potential of China and "maritime Silk Road" ASEAN countries}

After the Southeast Asian financial crisis in 1998, the gradual economic recovery, accelerate the cooperation between ASEAN and China's economic and trade cooperation to accelerate the improvement of the mechanism, the trade scale Chinese and ASEAN are 
increasing, mutual trade status gradually highlights. ASEAN has become China's fifth largest trading partner for 15 years, in 2009, ASEAN has become China's third largest export market. In 2010, Chinese-ASEAN Free Trade Area officially completed and the global economic recovery, Chinese and ASEAN import and export trade rebound strongly which trade volume reached 292 billion 760 million dollars, the rate of growth was $37.45 \%$; in 2013, the trade volume was 362 billion 854 million dollars, the rate of growth reached $23.94 \%$; In 2015, the trade volume was 4000.9 yuan, increased by $10.26 \%$ over last year. Although the rate of growth was lower in the past two years, higher than the average growth rate of China's external trades by $6.2 \%$, of which exports grew $20.1 \%$, and higher than the average growth rate of China's export abroad $7.9 \%$. Comparatively speaking, the import demand in Southeast Asia is growing at an average annual growth rate of $10.45 \%$ between 2000 and 2015, higher than that of China and Southeast Asia, which indicates that China has the potential to expand the trade scale between China and ASEAN. China and South Asia with 10 countries of the Persian Gulf has the strong complementary in economic structure, China's manufacturing at a higher level, South Asia and the Persian Gulf countries are rich in resources, promote the rapid development of economy and trade between china and the Persian Gulf. Over the past 10 years, the trade volume that China with South Asia and the Persian Gulf increased rapidly from 2000 to 2015 , the total trade volume increased from 5 billion 700 million dollars to 93 billion dollars, the average annual growth rate over $26 \%$, which imports volume from South Asia and the Persian Gulf countries grew from 1 billion 900 million dollars to 22 billion 600 million dollars, an average annual increase growth rate about $23 \%$. This momentum is good, an average annual growth rate of china was higher than the 10 countries in South Asia and the Persian Gulf imports needs $15.88 \%$, need to maintain the rapid growth of the situation.

\subsection{To strengthen the construction of the maritime Silk Road in 21th Century, China's Countermeasures}

By analysis, we can know that get the support which Chinese construction of "maritime Silk Road" strategy in the import countries along the rapid rise in demand and rapid changes in the structure of demand, and the China and the international economic and trade cooperation is still at a relatively low level, according to the change of the situation, take effective measures to Rapid advancement of China's strategic implementation, Rapidly implementation of the strategy that the construction of the " $21^{\text {th }}$ Century Maritime Silk Road by china and other countries.

3.2.1 Pay attention to the real needs of all countries in the maritime Silk Road, from the point of view of production and supply, rational allocation of elements and various resources
In the new maritime Silk Road along the country, between Chinese and ASEAN Economic and trade relations more closely, therefore, Chinese with new maritime Silk Road along the national economic and trade cooperation will have great development space and opportunities. For the maritime Silk Road along the country's strong import demand, increase the market research of these countries, to inform all types of enterprises on the demand for the country along the dynamic information. Secondly, from the macro, to strengthen the planning and policy guidance, and promote the common development of all countries in $21^{\text {th }}$ Century maritime silk road".

\subsubsection{Strengthen economic and trade cooperation with the new maritime Silk Road along the country of resource intensive industries}

New maritime Silk Road along the Southeast Asian countries are developing countries, many countries both resource reserves and supply power, and resource needs of the country. Most of the construction of industrialization and urbanization, the need for a large number of resources, but the technology about development of resources and processing is insufficient, it is difficult to transform their own resources available resources. Chinese economic transformation also requires a lot of imported resources, and has some technical advantages in resource processing, and strengthen the new maritime Silk Road countries along the internal trade of resource intensive industries, using the China processing technology advantage to strengthen investment in these countries.

\subsubsection{To reduce the output of labor-intensive products, expand the labor-intensive industries to go out"}

New maritime Silk Road along the national labor intensive products import has low proportion, Continue to decline, China export sector must reduce the export of labor-intensive products, make use of resources more reasonable and efficient, and ultimately serve the upgrading of industrial structure in china. Some countries also have new maritime Silk Road along the population and labor advantages, many years of development of labor intensive industry has accumulated rich experience and capital in china, and expanding along the national investment.

\subsubsection{Vigorously promote capital intensive product technology level and competitiveness}

New maritime Silk Road along the national import of capital goods is weak, Southeast Asia countries imported capital goods is relatively stable, South Asian countries along the capital goods imports showed a downward trend, capital goods market competition intensifies, increased the market risk that China exports capital goods to countries along the line . China must vigorously promote the quality of heavy industry, 
equipment industry product quality, strengthen brand development, thereby enhancing the capital intensive industrial competitiveness.

\subsubsection{To strengthen technological innovation, improve the competitiveness of technology intensive products}

New maritime Silk Road along the national technology intensive products import proportion is low, and the Southeast Asian countries and technology intensive products imports accounted for a substantial decline. South Asian countries along the technology intensive imports of products accounted for relatively low and slow down. The competitiveness of China's technology intensive products has been enhanced, we must continue to continually introduce new technology products. take China and Africa as an example, the two countries are to a large extent by the advantage of labor-intensive industry to participate in international market competition, in order to maintain a competitive advantage in the economy has similar export structure, Chinese export enterprises should use the technology transfer and technology innovation and development with advanced technology exports, promoting the innovation of technology innovation in China ,to improve the technological content of export products, improve the export structure, in order to win in the international competition.

Table 1. 2015 economic data of China and the maritime Silk Road between ASEAN and South Asian countries.

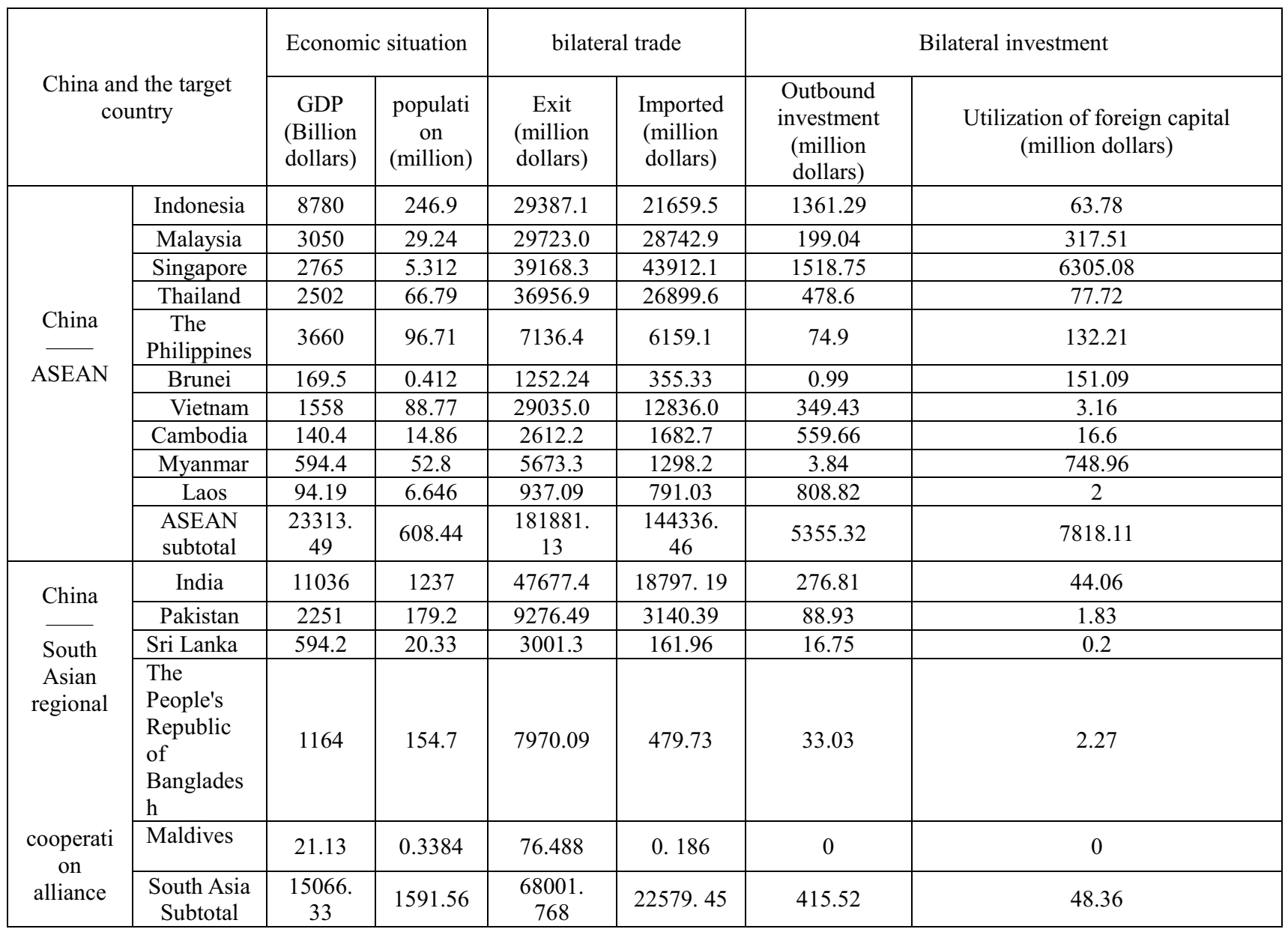

3.2.6 Speed up the "going out", to increase investment in the countries along the Silk Road, to improve the competitiveness of enterprises

China with ASEAN, South Asia countries bilateral investment scale are relatively small, direct investment in China is a late start to these countries, compared with the direct investment by the Southeast Asian countries, the scale is not large. Thus, in the "going out" strategy under the guidance of China should gradually pay more attention to the southeast and
South Asian countries investment, increase foreign investment, make full use of the host country resources and preferential policies to reduce the production cost.

\section{References}

1. The "State Council Qiaoban: expand public diplomacy、 the use of overseas resources such as China "The Belt and Road construction must make efforts in five aspects", zaobao. com, Http://www.zaobao.com/news/china/story201501 
25-4391552015 in January 25th.

2. Y. S. Lv, Academic Forum, 12, 29-35(2013).

3. F. Y. Zhou, The Study on the Problem Of Nanyang, 3, 17-22(2014).

4. Y. H. Mao, S. W. Yang, International Trade
Exploration, 4, 101 112(2015).

5. P. Han, Ocean Development and Management, 6, 52-54 (2015).

6. X. Y. Li, World Economics and Politics, 11, 4-17(2014). 